The Common Agricultural Policy of the European Union the present and the future

EU Member States

point of view 



\section{INSTITUTE OF AGRICULTURAL AND FOOD ECONOMICS NATIONAL RESEARCH INSTITUTE}

\section{The Common Agricultural Policy of the European Union - the present and the future}

\section{EU Member States point of view}

Editors:

dr Marek Wigier

prof. dr hab. Andrzej Kowalski

Proceedings of the International Scientific Conference

"The Common Agricultural Policy of the European Union - the present and the future" Multi-Annual Programme 2015-2019

"The Polish and the EU agricultures 2020+. Challenges, chances, threats, proposals" 5-7 December 2017 Stare Jabłonki, Poland

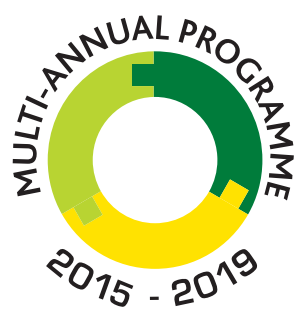

THE POLISH AND THE EU AGRICULTURES 2020+ CHALLENGES, CHANCES, THREATS, PROPOSALS

Warsaw 2018 
This monograph was prepared under the Multi-Annual Programme 2015-2019

"The Polish and the EU agricultures 2020+. Challenges, chances, threats, proposals".

The publication is a collection of selected papers delivered at the 22th edition of the International Scientific Conference organized by the Institute of Agricultural and Food Economics - National Research Institute. The theme of the conference was "The Common Agricultural Policy of the European Union the present and the future. The conference was placed on 5-7 December 2017 in Stary Jabłonki in Poland. Common Agricultural Policy was and still is one of the key pillars of European integration. Published in two volumes materials refer directly to the current and future of the CAP in EU and non EU member states, the strategic objectives and principles of agricultural policy for the agri-food sector and rural areas, address the issues of equilibrium between agriculture, forestry and land use, relate to the dilemmas for the EU budget and the CAP after 2020, CAP instruments and their adjustment, transformations of the rural economy and programming of the rural and agricultural policy, as well as productivity and production efficiency and tensions between sectoral action and between different models of territorial activities.

In the Scientific Committee of the Conference was participated: Prof. Andrzej Kowalski (IAFE-NRI, Poland), Prof. Drago Cvijanonivić (University of Kragujevac, Serbia), Prof. Thomas Doucha (IAEI, Czech Republic), Noureddin Driouech, PhD (CIHEAM, Italy), Prof. Szczepan Figiel (IAFE-NRI, Poland), Prof. Masahiko Gemma (Waseda University, Japan), Prof. Wojciech Józwiak (IAFE-NRI, Poland), Prof. Jacek Kulawik (IAFE-NRI, Poland), Prof. Yuriy Oleksiyovych Lupenko (IAE, Ukraina), Prof. Věra Majerová (CULS, Prague), Prof. Dimitre Nikolov (IAE, Bulgaria), Maire Nurmet, PhD (EMÜ, Estonia), Prof. Gabriel Popescu (ASE, Romania), Norbert Potori, PhD (AKI, Hungary), Prof. Włodzimierz Rembisz (IAFE-NRI, Poland), Piotr Szajner, PhD (IAFE-NRI, Poland), Prof. Alina Sikorska (IAFE-NRI, Poland), Prof. Jonel Subić (IAE, Serbia), Prof. Samuele Trestini (UNIPD, Italy), Prof. Olga Varchenko (Bila Tserkva National Agrarian University, Ukraine), Dipl.-Ing. Klaus Wagner (AWI, Austria), Marek Wigier, PhD (IAFE-NRI, Poland), Prof. Józef St. Zegar (IAFE-NRI, Poland)

In the Organising Committee of the Conference was participated: Małgorzata Bułkowska (IAFE-NRI, Poland), Anna Hankiewicz (IAFE-NRI, Poland), Joanna Jaroszewska (IAFE-NRI, Poland), Joanna Korczak (IAFE-NRI, Poland), Krzysztof Kossakowski (IAFE-NRI, Poland), Irena Mikiewicz (IAFE-NRI, Poland), Małgorzata Mikołajczyk (IAFE-NRI, Poland), Lech Parzuchowski (IAFE-NRI, Poland), Ewa Sierakowska (IAFE-NRI, Poland), Paulina Smakosz (IAFE-NRI, Poland), Leszek Ślipski (IAFE-NRI, Poland), Marek Wigier, PhD (IAFE-NRI, Poland).

Reviewers:

Professor Dimitre Nikolov, Institute of Agricultural Economics, Sofia, Bulgaria

Professor Gabriel Popescu, The Bucharest University of Economic Studies, Bucharest, Romania

Professor Samuele Trestini, University of Padva, Italy

Proofreader

Katarzyna Mikulska

Technical editors:

Joanna Jaroszewska, Barbara Pawtowska, Ewa Sierakowska, Kamila Tomaszewska,

Barbara Walkiewicz

Translated by

Summa Linguae S.A.

Cover Project

Leszek Ślipski

ISBN 978-83-7658-743-1

DOI: $10.30858 / \mathrm{pw} / 9788376587431$

Instytut Ekonomiki Rolnictwa i Gospodarki Żywnościowej

- Państwowy Instytut Badawczy

ul. Świętokrzyska 20, 00-002 Warszawa

tel.: (22) 5054444

faks: (22) 5054636

e-mail:dw@ierigz.waw.pl

http://www.ierigz.waw.pl 


\section{Contents}

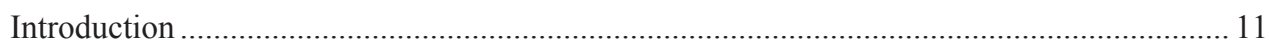

Dr Marek Wigier

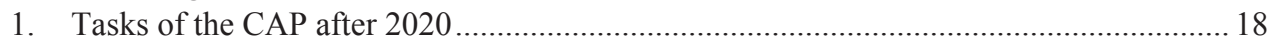

Dr hab. Julian Krzyżanowski

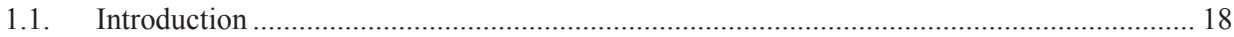

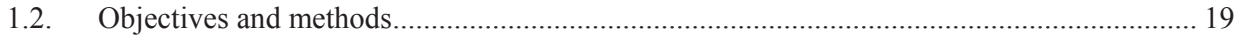

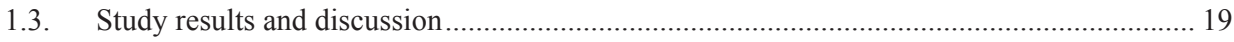

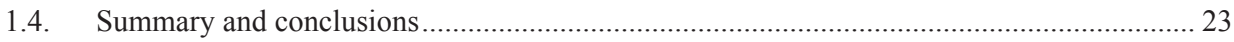



2. An assessment of the regional impacts of post-2020 CAP budgetary cuts on production

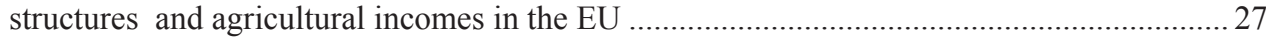

PhD Norbert Potori, PhD János Sávoly, PhD Szabolcs Biró

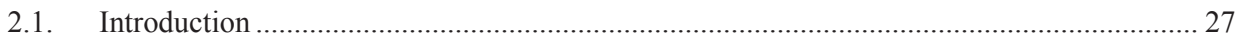

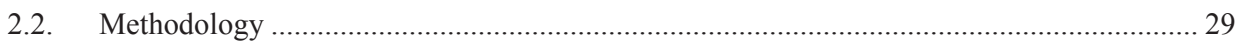

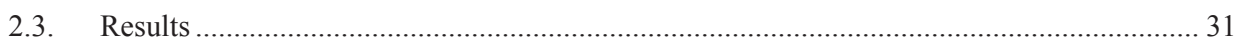

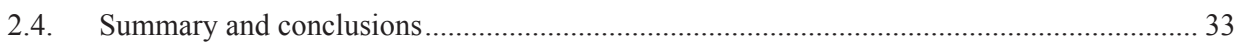

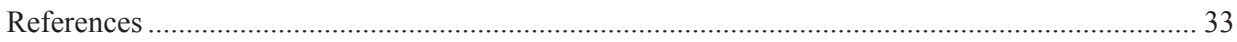

3. Is there room for financial instruments in the Common Agricultural Policy? Casus of

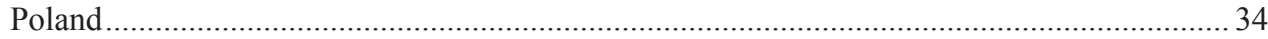

Prof. dr hab. Jacek Kulawik, PhD Barbara Wieliczko, PhD Michat Soliwoda

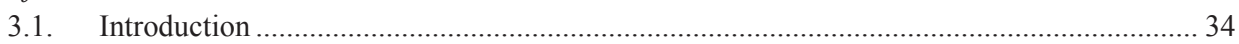

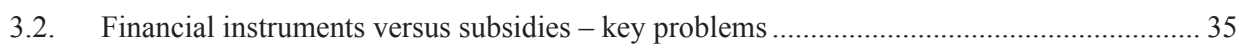

3.3. The use of financial instruments under the EU policy ......................................................... 37

3.4. Example of the use of FI in the 2014-2020 programming period ......................................... 38

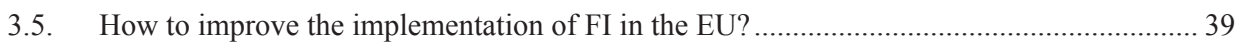

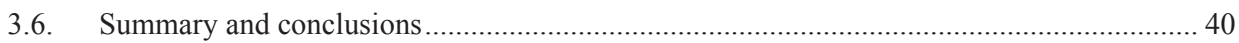

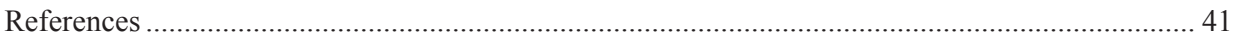

4. The past, present and future of the CAP - the Hungarian viewpoint ............................. 43

Dr Tamás Mizik

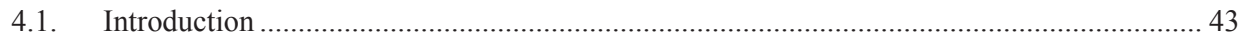

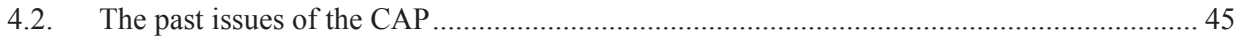

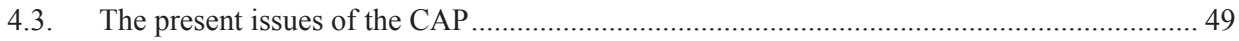

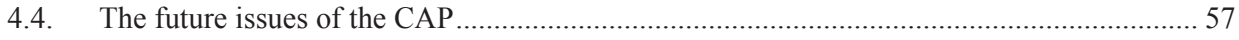

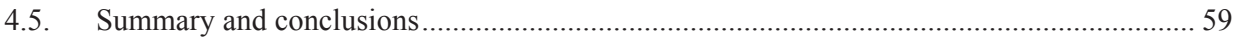

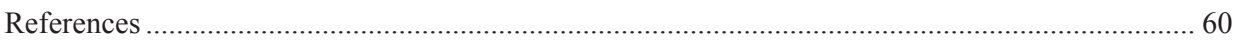


5. Going beyond the Rural Development Programme: a Master Plan for Austria's rural areas in the framework of the CAP

Dip.-Ing. Klaus Wagner

5.1. Introduction

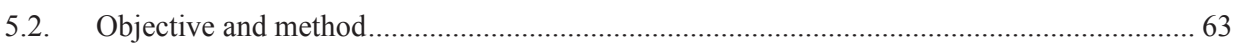

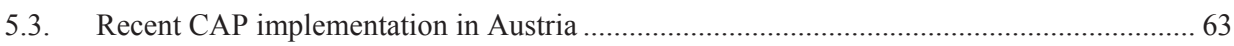

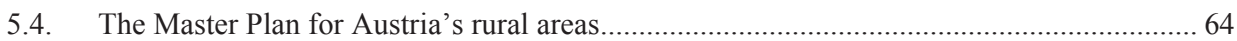

5.5. CAP in the system of the EU policy objectives and in the view of regional science

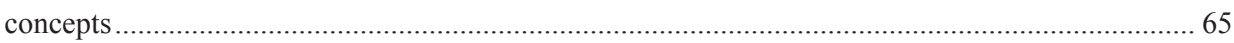

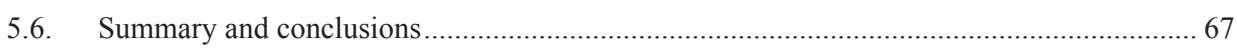

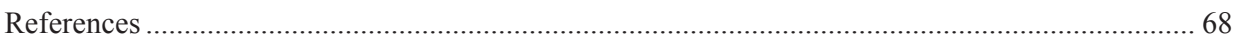

6. Possibilities to connect the Romanian agricultural research to the market requirements 69 Prof. Gabriel Popescu

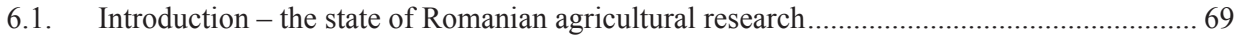

6.2. The problems faced by agricultural research since 1990 ..................................................... 71

6.3. Possible solutions for the recovery of Romanian agricultural research ................................ 76

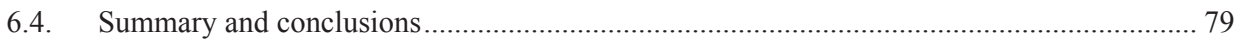

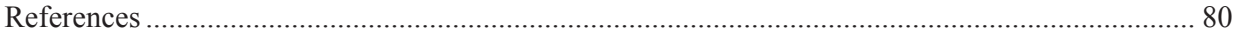

7. Price relationships of the production factors as exogenous determinants of production in agriculture.

Prof. dr hab. Włodzimierz Rembisz, PhD Adam Waszkowski

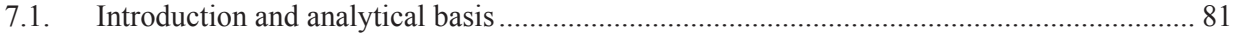

7.2. Relationships of prices of the capital, labour and land factors - hypothetical approach...... 83

7.3. Relationships of prices of the capital, labour and land factors - empirical approach .......... 84

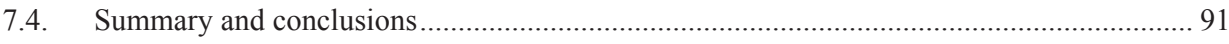

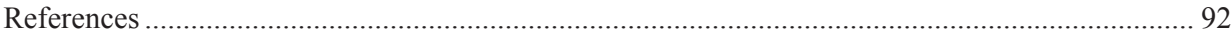

8. Effects of direct payments on agricultural development in Bulgaria ............................. 93 PhD Bozhidar Ivanov

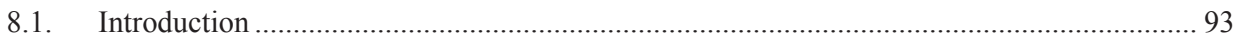

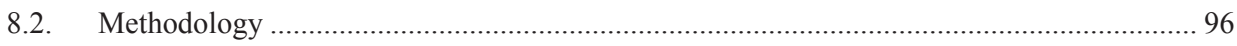

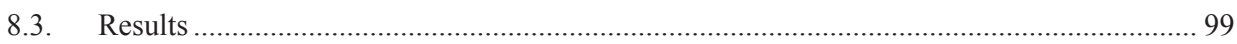

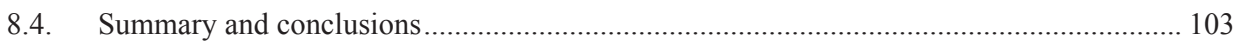



9. Re-adjusting risk management within the CAP: evidences on the implementation of the

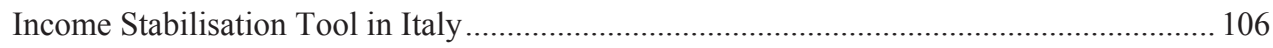
Prof. Samuele Trestini, PhD Elisa Giampietri

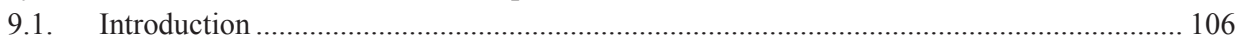

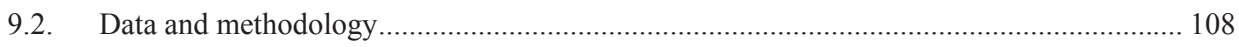




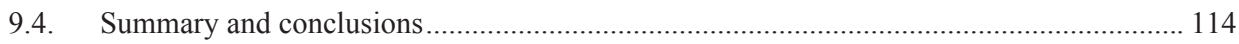

References

10. Comparison of risk management tools under the CAP of the EU, the US Farm Bill


Ing. Václav Vilhelm, CSc., Ing. Sumudu Namali Gouri Boyinová, PhD Jindřich Špička

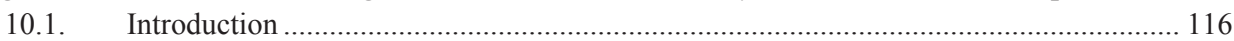

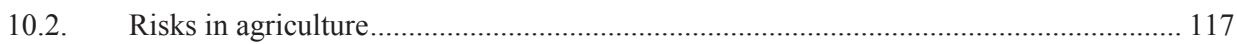

10.3. Risk management policy in the United States Farm Bill 2014 _..................................... 118

10.4. Risk management policy of the European Union's CAP ................................................ 119

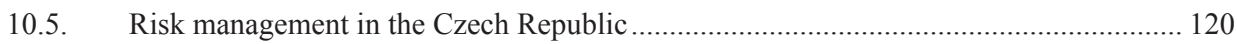

10.6. Comparative analysis of risk management policies ........................................................ 121

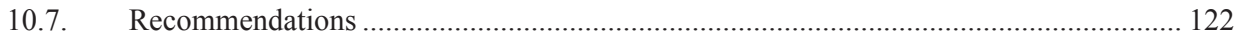

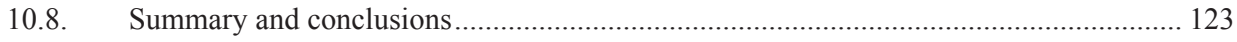

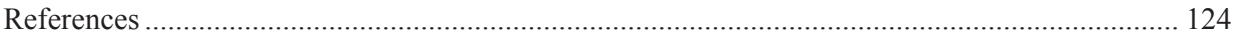

11. Factors determining the crop insurance level in Poland taking into account the level

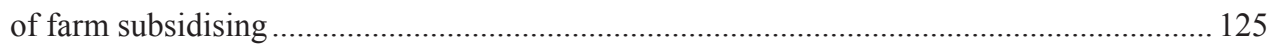

Prof. Adam Was, PhD Pawet Kobus

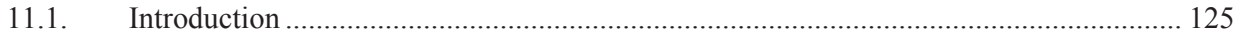

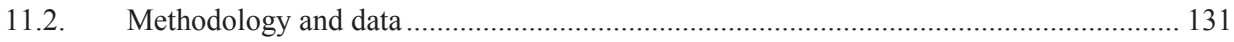

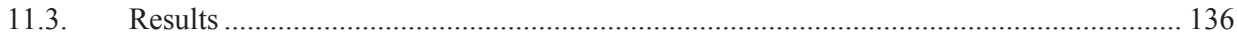

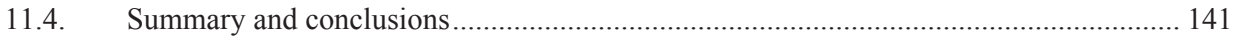

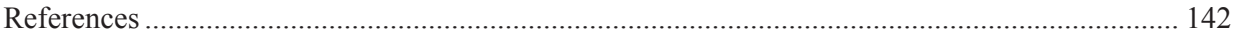

12. Farms and agricultural enterprises for development of sustainable and smart cooperatives: a multifactor approach using digital farm management ............................... 147 Prof. dr habil Adriana Mihnea, Prof. dr Dimitre Nikolov, dr Krasimir Kostenarov

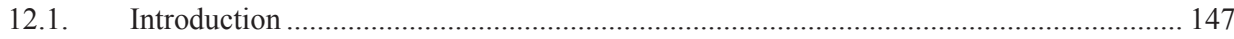

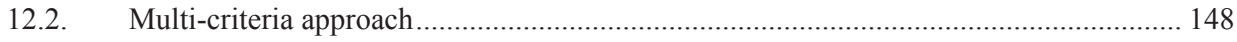

12.3. Construction of Farm Management Model ................................................................ 150

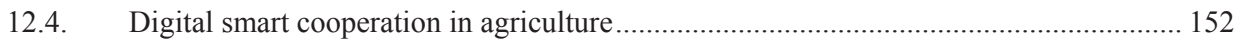

12.5. Application of the ANP Farm Management Model ....................................................... 154

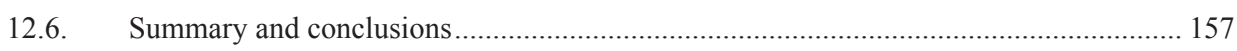



13. Brexit - potential implications for the Polish food sector .............................................. 159

Dr Katarzyna Kosior, Dr Łukasz Ambroziak

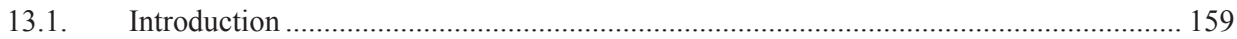

13.2. Negotiations on Brexit - what should be the model of the future relations? ..................... 161

13.3. The future of the EU finances and the CAP in the context of Brexit .............................. 163 
13.4. Impact of possible changes in the CAP budget on the net balance of Poland and transfers to the Polish agriculture.

13.5. The potential impact of Brexit on agri-food trade between Poland and the United

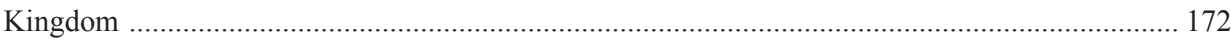

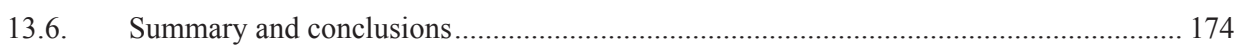

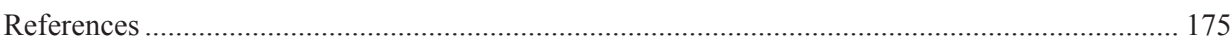

14. The Transatlantic Trade and Investment Partnership (TTIP): a threat or an opportunity for the EU-Mediterranean agriculture and agri-food sector? An exploratory survey ........... 177 Dipl.-Ing. Katja Pietrzyck, PhD Noureddin Driouech, Prof. Brigitte Petersen

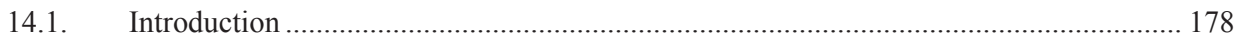

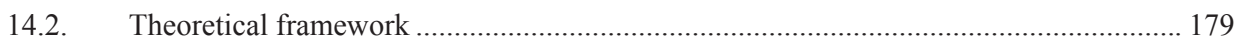

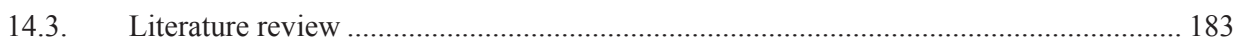

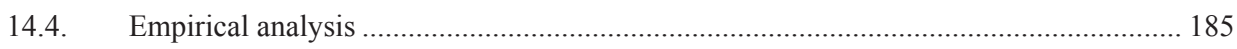

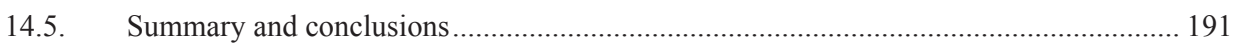

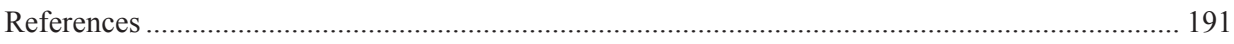

Appendix I: Overview of trade statistics regarding selected products ........................................... 195

15. The concept of short supply chains in the food economy............................................. 196

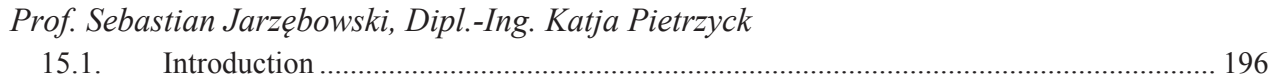

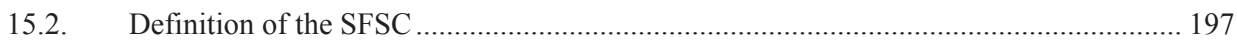

15.3. Development of short supply chains in Europe............................................................. 201

15.4. Global context of European short supply chains ........................................................... 205

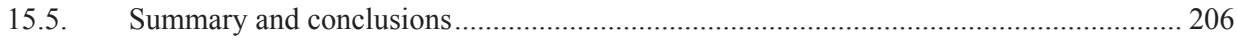

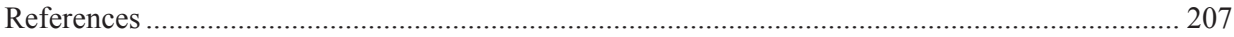

16. The CAP implementation in Wallonia - today performance and questions for the future -

A brief supplementary comment from Warmia and Mazury perspective............................. 209

PhD Philippe Burny, PhD Benon Gazinski

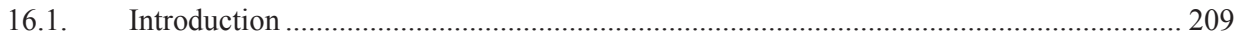

16.2. Implementation of the green payment in Wallonia in 2015 ........................................ 210

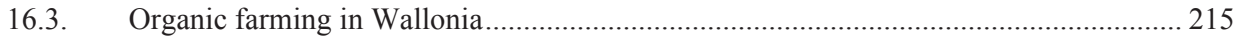

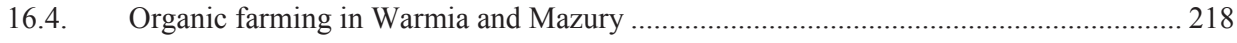

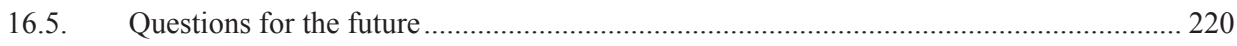

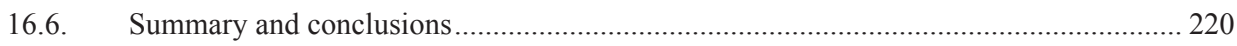

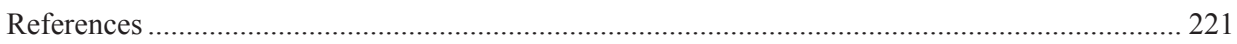

17. Afforestation of agricultural land financed from the RDP 2014-2020 ....................... 224

PhD Marek Zieliński

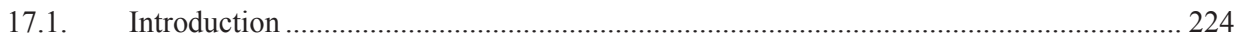

17.2. Natural farming conditions in Poland in regional terms................................................. 225 
17.3. The impact of natural farming conditions in Poland on the economic situation and the possibility of afforestation on farms

17.4. Land afforestation financed from the RDP 2014-2020 in regional terms

17.5. Importance of land afforestations financed under the RDP 2014-2020 in the EU climate policy for 2021-2030.

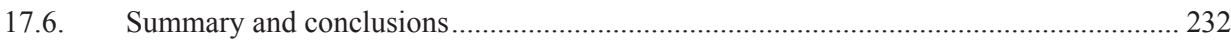

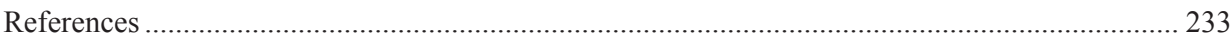

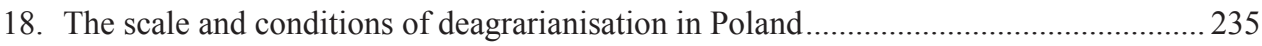

PhD Michat Dudek, PhD Bożena Karwat-Woźniak

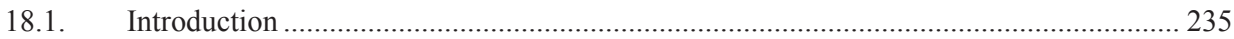

18.2. The conditions of the decrease in employment in agriculture ......................................... 236

18.3. The change in the scale of employment in agriculture in Poland and its conditions....... 238

18.4. The instruments of the Cohesion Policy and agriculture and rural development of the EU

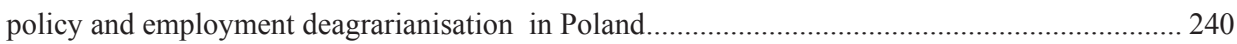

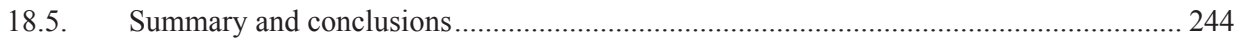

References 245

19. Socio-economic and environmental parameters and results of rural development under the CAP: the case of Bulgaria ................................................................................................ 247 Prof.dr.hab. Julia Doitchinova, Prof.dr.hab. Ivan Kanchev, Ass.Prof. Ralitsa Terziyska PhD, Ass.Prof. Kristina Todorova PhD

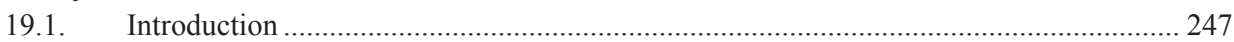

19.2. Changes in Bulgarian rural areas - socio-economic and environmental aspects................ 248

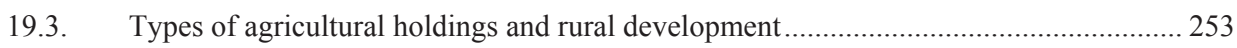

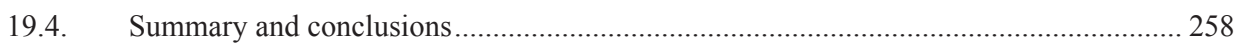

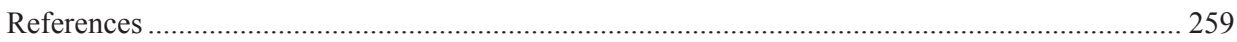

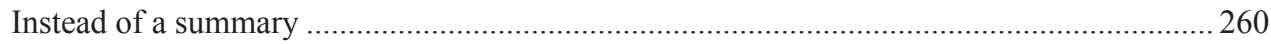

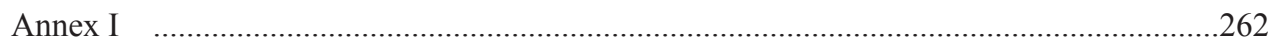




\title{
1. Tasks of the CAP after 2020
}

\author{
Dr hab. Julian Krzyżanowski \\ Institute of Agricultural and Food Economics - National Research Institute, \\ Warsaw, Poland \\ krzyżanowski@ierigz.waw.pl
}

DOI: $10.30858 / \mathrm{pw} / 9788376587431.1$

\begin{abstract}
In the current discussion on the future of CAP after 2020, not much is being said on the issues of real importance for agriculture and rural development in the EU Member States. The EU exposes mainly the passive protection and simplification tasks. No expansion vision is in place. We may assume that the chief CAP objective is assurance of sustainable development. This type of development has numerous exogenous determinants: global, economic, environmental, and endogenous, existing in agriculture. It results from the EU membership as well as greater links between European and world agriculture. We have also internal determinants both in the rural environment and production process. The external and internal situation imposes drawing of ambitious and expansive goals and tasks for CAP. One has to remember that goals that justify existence of CAP for taxpayers cannot obscure the ideas that are basic for agricultural and rural development.
\end{abstract}

Keywords: agriculture, European Union, CAP, sustainable development

JEL codes: A10, E00, F10, F15, F53, Q18

\subsection{Introduction}

Among the various concepts related to the economic integration, including the integration in agriculture, considerations regarding scientific foundations for the Common Agricultural Policy we can also find theories on the CAP reform. In analysing the modern hypotheses, the theory of the reform of the Common Agricultural Policy by A. Kay [2000] should be invoked. According to the English scientist "the interactions of different EU institutions and Member State governments is the main dynamic behind a reform process". This paper is one of the proofs of this hypothesis.

A discussion on the future of the European Union's Common Agricultural Policy after 2020, initiated by the European Commission some time ago, has intensified in the last two years (2016-2017). A public consultation on "Modern- 
isation and simplification of the CAP" [Council of the European Union , 2017] was launched, with a number of debates such as an informal meeting of the Ministers of Agriculture in Amsterdam, meeting of the Ministers of Agriculture in Chambord, meeting of the Council for Agriculture and Fisheries in November 2016, European Conference on Rural Development Cork 2.0 in September 2016 [CORK 2.0, 2016], many debates in the European Parliament, to name a few.

\subsection{Objectives and methods}

The objective of this paper is to present the tasks which should be implemented by the Common Agricultural Policy after 2020. These tasks are presented on various forums and discussed. The author of the concept is either the European Commission or the European Union Member State, currently presiding the Council. The formulated tasks have been confronted by the author with the provisions of the Treaties, from the Treaty of Rome to the Treaty on the Functioning of the European Union. Then, the opinions of the individual Member States as to the proposal of the Maltese presidency were presented. Also, the provisions formulated in the Communication from the European Commission on "The Future of Food and Farming" of 29.11.2017 have been presented. On this basis, it is attempted to formulate conclusions on the CAP objectives to be defined and adopted, taking into account various current conditions for the rural and agricultural development. The paper used the method of analysis of the European Union documents.

\subsection{Study results and discussion}

The quoted document [Council of the European Union, 2017] collects, proposals developed at various meetings and presents priorities for further work, which include:

- $\quad$ Resilience building: this includes issues such as risk management in relation to weather, health or sanitary risks, access to financial instruments, income/price volatility, competitiveness and innovation and food security;

- $\quad$ Responding to environmental challenges: by increasing the sustainability of agriculture, implementing international commitments on climate after the Conference of the Parties (COP) [The International..., 2015], United Nations Framework Convention on Climate Change [UNFCCC, 2017] or the broader objectives included in the 2030 Agenda for Sustainable Development [UNIC, 2016];

- Guaranteeing the exchange of generations: by facilitating access to financial resources, land, through transfer of knowledge, vocational training and reducing administrative barriers; 
- Maintaining market orientation: which includes issues such as promoting competitiveness, finding the right balance between opening new markets and protecting sensitive sectors and improving the competitiveness of export;

- $\quad$ Empowering farmers: by addressing the issues of transparency, contractual relations and unfair commercial practices.

- $\quad$ Simplification should remain the overriding principle of the future CAP, not only at the legislative level, but also as regards the implementation and controls, as indicated in the Council Conclusions of May 2015 [Special Committee on Agriculture, 2015].

The Maltese Presidency, which was the basisfor the document, asked the Member States two questions: whether they agree with the above-mentioned set of priorities and whether it should be supplemented. Before we quote the responses of the individual countries, the more general question can be asked: are these the most important objectives for agriculture and rural development? has this been written in the TFEU like that?

It can be concluded that in their responses the Member States retained the presence of mind and knowledge of the principles of the Common Agricultural Policy. Let us remind that Article 39 of the Treaty on the Functioning of the European Union, repeating the provisions of the Treaties of Rome, sets out the specific objectives of the CAP [Damen and Przetacznik, 2017]:

- $\quad$ To increase agricultural productivity by promoting technical progress and the optimum utilisation of the factors of production, in particular labour;

- To ensure a fair standard of living for the agricultural community;

- To stabilise markets;

- To assure the availability of supplies;

- To ensure that supplies reach consumers at reasonable prices.

These are both economic and social objectives aimed at protecting the interests of producers and consumers. In addition to the specific objectives of the CAP, as provided in Article 39 of the TFEU, many provisions of the Treaty provide for additional objectives applicable to all policy areas and to all Union actions. Consequently, the promotion of the high level of employment (Article 9), environmental protection to promote the sustainable development (Article 11), consumer protection (Article 12), animal welfare requirements (Article 13), protection of public health (Article 168(1)) or economic, social and territorial cohesion (Articles 174-178) become fully the CAP objectives. Moreover, in the context of the opening and globalisation, Article 207 lays down the principles of the common commercial policy relating to trade in agricultural products. However, should the additional objectives dominate the basic objectives? 
It can be said that this has actually happened. The so-called "greening", introduced by the reform of 2013 and, in fact, a discussion taking place in the EU forum since 2010, officially advocated the sustainable development and dominated the tasks of the CAP at the beginning of the present perspective [Krzyżanowski, 2015]. Regardless of introducing the noble environmental protection objectives [Communication, 2010], the point was to justify the need to pay for the Common Agricultural Policy, i.e. agriculture and rural development, in the eyes of taxpayers in the Member States.

Figure 1. Elements of the debate on the CAP after 2020

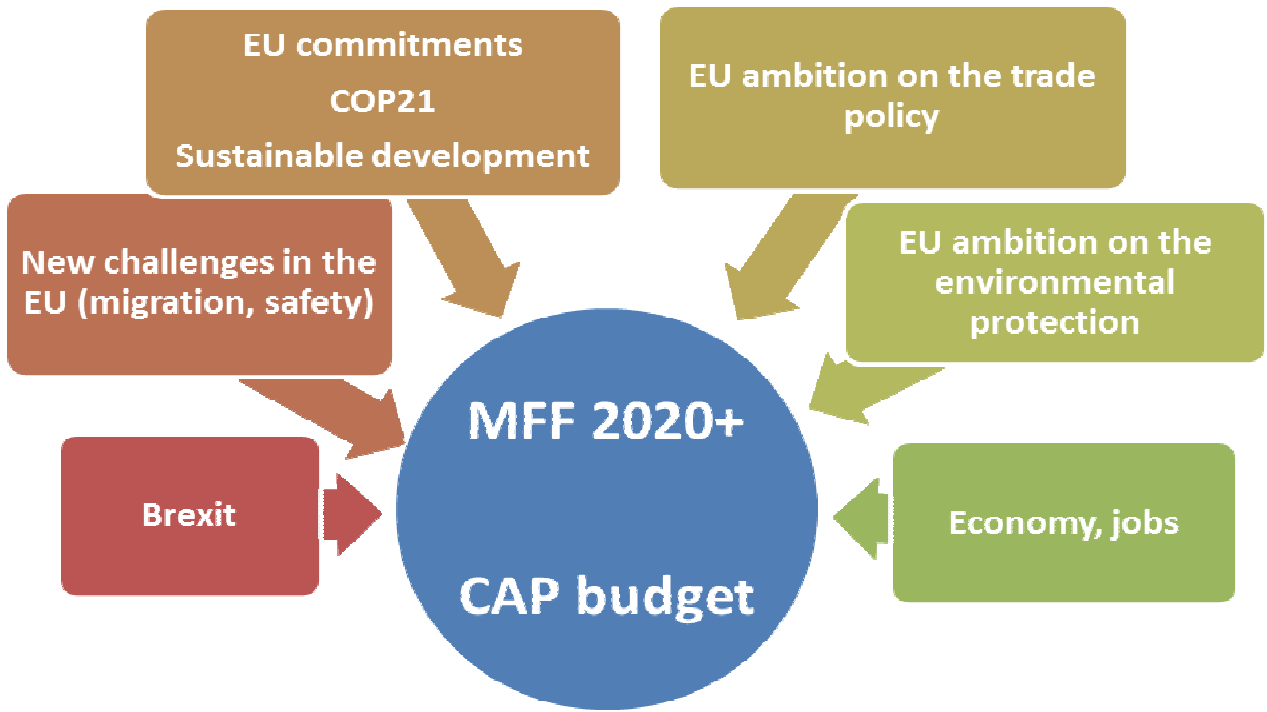

Source: Common Agricultural Policy after 2020 - Polish priorities, Ministry of Agriculture and Rural Development, Łomża 2017.

The Member States in their statements at the meeting of the Council of Ministers [Report, 2017], in the vast majority opted for the classic model of the CAP (two pillars). This was not mentioned only by Germany, Denmark, the Netherlands and Portugal. Most countries also stress the importance of direct payments to the amount of agricultural income and production. Only four abovementioned countries do not comment on this. In analysing the discussion of the Member States on the Presidency's document [Report, 2017], it can be concluded that the Member States were almost fully unanimous in relation to one priority only, i.e. simplification of the CAP. The simplification was not mentioned as an important priority only by six countries: Austria, Bulgaria, Cyprus, Estonia, Spain and Ireland. The opinions were more divided in terms of the issue of risk management: 17 countries, including Poland, opted for recognising this instruments as a priority and important task for the CAP. 
The importance of the problem is well illustrated by the position of Germany: "Focusing on the environmental issues only, is an excessively restricted view of the needs of the agricultural sector." In the course of numerous discussions on the future of the CAP, which have taken place in recent years, also the challenges that the Common Agricultural Policy can/should face, have been mentioned (Fig. 1).

As we can see, there is neither agriculture nor farmers here. Both categories are buried deeply under a layer of general tasks and commitments.

Another light on the tasks of the CAP in the next financial perspective is cast by the European Commission's Communication "The Future of Food and Farming" published at the end of November 2017 [Communication, 2017]. The CAP is to play an important role in achieving the priorities of Jean-Claude Juncker in full cohesion with other policy areas, in particular by:

- Increasing the number of high-quality jobs and stimulating growth and investment;

- Using the potential of the Energy Union, circular economy and bioeconomy, while increasing the environmental concern and mitigating and adapting to climate change;

- Transfer of research and innovation from laboratories to fields and markets;

- Full inclusion of farmers and rural areas in the digital economy; and

- Contributing to the implementation of the European Commission's Programme on migration.

Among 17 Sustainable Development Goals by 2030, promoted by the United Nations, 12 are directly or indirectly implemented through the activities of the Common Agricultural Policy.

The further part of the Communication lists the main objectives of the future CAP [Communication, 2017, p. 12]:

- $\quad$ Promoting smart and resilient agricultural sector;

- Increasing the environmental concern and stepping up climate action to contribute to achieving the EU environmental and climate change objectives;

- $\quad$ Strengthening the socio-economic structure of rural areas.

The same is shown in the Figure 2. As directly visible, the farmer is indicated only twice, but he is to be the beneficiary of all other actions. 
Figure 2. Future of food and farming



Source: Communication, 2017.

\subsection{Summary and conclusions}

Unfortunately, the priorities indicated in the Presidency's document, and above all in the Communication, do not take into account the essential tasks of the Common Agricultural Policy, which are also important for Polish agriculture and rural development. Firstly, it is important to ensure a level playing field in the European market. The Common Agricultural Policy should, in fact, create a common legal and financial framework for the functioning of the agricultural sector in the EU. This task is now gaining importance, inter alia, due to the fact that the instability in the agricultural markets and the increasing price and cost pressure make some countries take protectionist action in the EU single market.

The second, still up-to-date task of the CAP, is to strengthen cohesion in the EU, in economic, social and political terms. The CAP should reduce disparities in the agricultural and rural development levels, both among the regions and Member States.

How can these tasks be accomplished? A key issue is to provide an adequate, fully Community budget for this policy. The relevant CAP budget is a prerequisite for the implementation of the priorities identified by the Presidency. In order to ensure a level playing field in the EU single market, it is necessary to complete the process of full alignment of direct payment rates. One of the possible solutions is the proposed distribution of direct support among the 
Member States on the basis of a flat-rate throughout the EU [Krzyżanowski, 2015]. The flat- rate corresponds well to the current and future objectives of the CAP - in particular, with the environmental and climate objectives [Common 2017]. The issue of alignment of payments was also raised in the subsequent versions of the Communication "The Future of Food and Farming". Unfortunately, the later is the version of the document, the more imprecise are the initial provisions. The authors refer to the words by President Juncker who stated "that we need to implement the principle of equality among the large and small countries, East and West, North and South, even though labour costs differ, the challenges faced by farmers are similar". The first versions of the Communication talk about the "reduction in the differences among average payment rates in the Member States", which is to be understood as alignment of the level of payment and the final version generally talks about the "reduction in the differences of support under the CAP" which does not necessarily mean alignment of payments, but support e.g. for climate change measures.

When looking at the new solutions through the prism of the interests of Polish agriculture, it should be assumed that the fund allocation criteria in the second pillar of the CAP should (as it has been so far) take account of the differences in the wealth of rural residents, their population and the area of agricultural land. Instruments of the common organisation of agricultural markets should be used more rapidly and actively so as to counter agricultural crisis situations.

The European Union should go with the CAP rules beyond the grouping and be a challenge in relation to the policies of other regions of the world. In particular, the EU countries are to be treated equally. The CAP after 2020 should be implemented in such a way so that it could create opportunities for the competitiveness of the EU products in world markets, and it should also take into account the solutions used in other countries, e.g. in the field of state aid for agriculture (USA) [Krzyżanowski, 2016]. The CAP should be used not for eliminating the agricultural production but for its development, in connection with a forecast regarding the increased food demand in the world. The CAP should also include mechanisms to protect against the allocation of agricultural land for non-agricultural purposes.

Certainly, an important, yet "secondary", task is to simplify the CAP financing scheme. It would be necessary to simplify the procedures for allocating and distributing financial resources, so as to reduce bureaucracy while reducing the costs of handling the CAP. Undoubtedly, the greening obligation is a political element for the citizens of Europe. The implementation of this system points once again to the role of farmers and agriculture in the environmental protection. Hence, if the greening needs to function, its rules should be simplified as much as possible. 
The above considerations fit in further analyses on the vision of the Common Agricultural Policy after 2020. The next stage of work will consist in publishing, by the Commission, of legislative proposals, which is foreseen in 2018. The new shape of the CAP will be finally determined by the Member State government (EU Council for Agriculture and Fisheries) and the European Parliament.

The Polish opinion in the discussion of the future of the CAP is a draft governmental position on the future of the Common Agricultural Policy [Ministry, 2017]. According to the Ministry of Agriculture, the Common Agricultural Policy is a comprehensive, fully Community policy of the EU, which is one of the cornerstones of the European Union. This policy implements an increasingly broader catalogue of public objectives and, through further reforms, responds to new challenges. The CAP is responsible for the level playing field in the single market, while deciding on the predictability and stability of the conditions of pursuing agricultural activities.

Also in the future, the CAP should provide the EU society with food independence, including access to high-quality food, while contributing to achieving the sustainable development goals, including the preservation of the resources of land, water and air and biodiversity for other generations.

The current legal solutions leave room for further modernisation of the CAP in an evolutionary way, without fundamental changes in the structure of this policy. The real simplification of individual instruments and of the entire CAP after 2020 requires, inter alia, greater confidence in the Member States in terms of planning, implementation and control in line with the principle of subsidiarity.

It is necessary to coordinate the CAP with other EU policies (e.g. trade, environmental, climate, energy, development, competition), which are increasingly affecting agriculture and the food production sector. The achievement of ambitious targets with regard to other Community policies will not be possible without the ambitious and fully Community agricultural policy.

May this clash of views between the Commission and the Member States bring the best possible solutions for the future of the CAP.

\section{References}

1. Communication from the Commission to the European Parliament, the Council, the European Economic and Social Committee and the Committee of the Regions (2010). The CAP Towards 2000: Meeting the Food, Natural Resources and Territorial Challenges of the Future. European Commission, COM 672.

2. Communication from the European Commission (2017). The Future of Food of Farming, European Commission, Brussels. 
3. CORK 2.0 (2016). Declaration 2016: A Better Life in Rural Areas. Retrieved from: https://ec.europa.eu/agriculture/sites/agriculture/files/events/2016/ruraldevelopment/cork-declaration-2-0_en.pdf.

4. Council of the European Union (2017). The future of the Common Agricultural Policy - preparation of the exchange of views at Council. Brussels, February 20, 6463/17.

5. Damen M., Przetacznik J. (2017). Unia Europejska i jej partnerzy handlowi. Retrieved from: http://www.europarl.europa.eu/atyourservice/pl/displayFtu.html? ftuId=FTU_5.2.1.html.

6. http://unfccc.int/essential_background/convention/status_of_ratification/items/26 31.php [accessed on 2017.08 15]

7. http://www.unic.un.org.pl/files/164/Agenda\%202030_pl_2016_ostateczna.pdf [accessed on 2017.08 15].

8. Kay A. (2000). Towards a Theory of the Reform of the Common Agricultural Policy. European Integration online Papers (EIoP), Vol. 4, No. 9, July 17. Retrieved from: https://papers.ssrn.com/sol3/papers.cfm?abstract_id=302759 [accessed in 2017].

9. Krzyżanowski J.T. (2015). European Union Common Agricultural Policy in Poland. CeDeWu, Warsaw.

10. Krzyżanowski J.T. (2016). Opportunities and risks to agriculture and food consumers in the European Union countries resulting from the potential TTIP agreement, "Issues of Agricultural Economics", No 3.

11. Ministry of Agriculture and Rural Development (2017). Common Agricultural Policy after 2020 - Polish priorities. Document adopted by the Council of Ministers on May 16.

12. Report on the meeting of the EU Council for Agriculture and Fisheries on 6 March 2017 (2017). MARD in-house materials.

13. Special Committee on Agriculture (2015). Draft Council conclusions on the simplification of the CAP. Brussels, May 5, Doc. No. 8485/15.

14. The 2015 international agreement - European Commission ec.europa.eu, 12 December 2015. 